\title{
THE EFFECT OF PH CHANGES ON CRYSTALLIZATION OF CALCIUM SALTS IN SOLUTIONS WITH AN ION-COMPOSITION CORRESPONDING TO THAT IN THE DISTAL TUBULE
}

\author{
Inge Højgaard, Anne-Marie Fornander, Mari-Anne Nilsson and Hans Göran Tiselius* \\ Department of Urology and Clinical Research Center, Faculty of Health Sciences, University Hospital, 58185 Linköping, \\ Sweden
}

(Received for publication October 25, 1996 and in revised form March 14, 1997)

\begin{abstract}
The effect of $\mathrm{pH}$ changes on the crystallization in solutions with an ion-composition assumed to correspond to that of urine in the distal part of the distal tubule was examined by recording the number and volume of crystals with a Coulter Multisizer and by studying the crystal morphology by scanning electron microscopy at different degrees of volume reduction. The experiments were carried out with $100 \mathrm{ml}$ samples at different starting $\mathrm{pH}$ without and with $20 \%$ of dialyzed urine (dU).

The number of crystals increased in response to volume reduction. In solutions without dU, 100 or more crystals with diameters in between 2.4 and $45 \mu \mathrm{m}$ were observed already at a volume reduction of $40 \%$ when the initial $\mathrm{pH}$ was 7.28. For solutions with $\mathrm{pH}$ of 5.80 and 6.45 , the corresponding values were $60 \%$ and $80 \%$, respectively. In the presence of dU, an appearance of crystals was recorded at volume reductions of less than $20 \%$. In solutions with an initial $\mathrm{pH}$ of 5.80 and 6.45 , the crystal number was greater with dU than without; such a difference was not recorded at $\mathrm{pH} 7.28$.

In samples containing dU, the mean crystal volume (MCV) varied very little when the sample volume was reduced. The same was found in solutions without dU when the initial $\mathrm{pH}$ was 5.80 and 7.28; the MCV was greater in the samples with $\mathrm{pH} 6.45$.

Scanning electron microscopy of solutions reduced to $30-40 \%$ of the original volume showed that calcium phosphate had formed in solutions with a starting $\mathrm{pH}$ of 7.28 and 6.45. In solutions with $\mathrm{pH} 5.80$, calcium oxalate crystals were observed with calcium phosphate.
\end{abstract}

Key Words: Crystallization, calcium phosphate, calcium oxalate, distal tubule, macromolecules, promotion, inhibition, $\mathrm{pH}$.

*Address for correspondence:

Hans Göran Tiselius, address as above.

FAX number: +46858587760

E-mail: Hans-Goran.Tiselius@uro.hs.sll.se

\section{Introduction}

The development of urinary stones is the result of a crystallization process that involves nucleation, crystal growth and crystal aggregation. The crystallization is, therefore, influenced by chelators as well as inhibitors and promoters of crystallization either with a low molecular weight, such as citrate, pyrophosphate, and urate, or with a high molecular weight, such as nephrocalcin, uropontin, Tamm-Horsfall protein, and glycosaminoglycans.

In two recent studies, we have shown that calcium phosphate $(\mathrm{CaP})$ might be the type of crystal that most easily forms in the proximal and distal tubule of the nephron (Lupták et al., 1994; Højgaard et al., 1996). In salt solutions with a $\mathrm{pH}$ of 6.45 , and an ion-composition assumed to correspond to that of urine in the distal tubule, $\mathrm{CaP}$ nucleation was induced both by an increased calcium concentration and by changes in solution composition brought about by volume reduction. Urinary macromolecules, thus, appeared to have a promotive effect on the nucleation of $\mathrm{CaP}$ and an inhibitory effect on crystal growth, crystal aggregation or both, since they counteracted the development of large $\mathrm{CaP}$ crystals or crystal aggregates.

It is well-known that urinary $\mathrm{pH}$ is of great importance for crystallization of both calcium oxalate $(\mathrm{CaOx})$ and CaP (Robertson et al., 1978; Tiselius, 1981, 1983; Berg and Tiselius, 1986; Hallson and Rose, 1989a, b; Grases et al., 1993). Most of these conclusions were based on experiments carried out in whole urine. It is also well-known that the influence on the crystallization process of both low and high molecular weight compounds depends on the $\mathrm{pH}$ (Smith, 1976; Wilson et al., 1985; Scurr and Robertson, 1986; Baumann et al., 1989; Hess et al., 1989; Coe et al., 1991; Boevé et al., 1994).

Since it is reasonable to assume that the first step in the crystallization process leading to pure $\mathrm{CaP}$ and mixed $\mathrm{CaOx} / \mathrm{CaP}$ stones starts in the loop of Henle (Coe and Parks, 1990; Kok, 1995; Asplin et al., 1996) or in the distal tubule (Lupták et al., 1994; Tiselius et al., 1999), we found it worthwhile to study the effects of $\mathrm{pH}$ on the crystallization of calcium salts in solutions with a composition corresponding to that in the distal tubule. 


\section{Material and Methods}

A salt solution with an ion-composition assumed to correspond to that of urine in the distal part of the distal tubule (DTd) was prepared as previously described (Lupták et al., 1994). One liter of this solution was given the following ion composition: $1.04 \mathrm{mmol}$ calcium, $0.41 \mathrm{mmol}$ magnesium, $4.17 \mathrm{mmol}$ phosphate, $0.04 \mathrm{mmol}$ oxalate, 0.35 mmol citrate, $96 \mathrm{mmol}$ sodium, $22.5 \mathrm{mmol}$ potassium and $13.8 \mathrm{mmol}$ sulphate. No ammonium was added to avoid the risk of precipitating ammonium salts.

The $\mathrm{pH}$ in the salt solution was adjusted to $6.45,5.80$ and 7.28 , by the addition of small amounts of sodium hydroxide or hydrochloric acid, in three different series. A $\mathrm{pH}$ of 6.45 was assumed to represent the average $\mathrm{pH}$ in the distal tubule under normal conditions (Rector, 1983). The $\mathrm{pH}$ in the samples was measured with a $\mathrm{pHM} 84 \mathrm{pH}$ meter (Radiometer, Copenhagen, Denmark) immediately before and after evaporation (see below).

We used pooled dialyzed urine from normal subjects as a source of macromolecules. This urine was collected between 2200 and 0600 hours in bottles containing $15 \mathrm{ml}$ of $3 \mathrm{mmol} / \mathrm{l}$ sodium azide as a preservative. The urine was screened for bacteria, protein and glucose before being pooled. The preparation of dialyzed urine (dU) was carried out as previously described (Højgaard et al., 1996). According to the degree of dilution at different nephron levels, the normal concentration of macromolecules in DTd was assumed to approximately correspond to a $20 \%$ concentration of dU. However, it needs to be emphasized that the concentration of Tamm-Horsfall protein and probably also other macromolecules might be lower than that normally found in distal tubular urine as a result of the sample preparation technique (Lupták et al., 1994).

Aliquots of $100 \mathrm{ml}$ of the salt solutions with and without dU were used in volume reduction experiments. These samples were passed through Millipore filters with a pore size of $0.22 \mu \mathrm{m}$ (Millipore S.A., Molsheim, France), after which evaporation was carried out in a Büchi Rotavapor $\mathrm{RE}$ at $37^{\circ} \mathrm{C}$ (Büchi AG, Flawil, Switzerland).

Immediately after the evaporation, the number and volume of crystals in the size interval 2.4 to $45 \mu \mathrm{m}$ were recorded in a Coulter Multisizer with a $100 \mu \mathrm{m}$ capillary tube (Coulter Electronic Ltd, Luton, U.K.). The mean crystal volume (MCV) was the quotient between the total volume $\left(\mu \mathrm{m}^{3}\right)$ and the total number of crystals.

A significant formation of crystals was not considered to have occurred until the number of particles in $50 \mu \mathrm{l}$ exceeded 100. This level was chosen to minimize the risk of drawing conclusions from counting non-crystalline material, as our method for particle detection did not allow a distinction between crystals and other particles. Based on previous microscopic observations, a nucleation is conceivable when 100 crystals are recorded.

Aliquots for examination of the crystal morphology was obtained from solutions both with and without dU immediately after the crystal counting. The samples were prepared for scanning electron microscopy as previously described (Lupták et al., 1994).

The ion-activity products of calcium oxalate $\left(\mathrm{AP}_{\mathrm{CaOx}}\right)$, brushite $\left(\mathrm{AP}_{\mathrm{Bru}}\right)$ and hydroxyapatite $\left(\mathrm{AP}_{\mathrm{HAP}}\right)$ were calculated by means of computerized iterative approximation with the EQUIL2 program (Werness et al., 1985) at different degrees of evaporation. As the $\mathrm{CaP}$ crystal phase that forms is highly dependent on the $\mathrm{pH}$, we also calculated the ionactivity product of $\mathrm{CaP}\left(\mathrm{AP}_{\mathrm{CaP}}\right)$ by means of the product of the activities of calcium and phosphate: $\mathrm{a}_{\mathrm{Ca}} 2+\cdot \mathrm{a}_{\mathrm{PO} 4} 3-$. Similar to our previous observations (Højgaard et al., 1996), the $\mathrm{pH}$ decreased following evaporation of solutions with a starting $\mathrm{pH}$ of 6.45 and 5.80, but not in solutions with a starting $\mathrm{pH}$ of 7.28 (Fig. 1). Therefore, we used the $\mathrm{pH}$ value recorded at the end-point of the volume reduction for calculation of the $\mathrm{AP}_{\mathrm{Bru}}, \mathrm{AP}_{\mathrm{HAP}}$ and $\mathrm{AP}_{\mathrm{CaP}}$. Figure 1 also shows the $\mathrm{pH}$ in solutions without calcium.

\section{Statistical analysis}

Regression analysis was used to record any association between different variables, and Student's t-test to decide on statistically significant differences.

\section{Results}

\section{Crystal number}

There was a linear relationship between the ${ }^{10} \mathrm{log}$ crystal number and the degree of volume reduction in solutions with $\mathrm{dU}$ at all three $\mathrm{pH}$ levels, the coefficients of correlation were statistically significant $(\mathrm{p}<0.001)$. This was not observed for solutions without $\mathrm{dU}$ and an initial pH of 5.80 and 6.45 (Fig. 2). As shown in Figure 2A, the number of crystals in solutions without $\mathrm{dU}$ and an initial $\mathrm{pH}$ of 6.45 did not exceed 100 until the volume had been reduced to $20 \mathrm{ml}$. In the presence of dU, this crystal number was exceeded already after an evaporation to $85 \mathrm{ml}$. In solutions with a starting $\mathrm{pH}$ of 5.80,100 crystals were recorded after a volume reduction to approximately $40 \mathrm{ml}$ without $\mathrm{dU}$ and 90 $\mathrm{ml}$ with $\mathrm{dU}$ (Fig. 2B). At a starting $\mathrm{pH}$ of 7.28, the number of crystals exceeded 100 after a volume reduction to $60 \mathrm{ml}$ without $\mathrm{dU}$ and $85 \mathrm{ml}$ in the presence of $\mathrm{dU}$ (Fig. 2C).

The number of crystals in solutions without $\mathrm{dU}$ and a starting $\mathrm{pH}$ of 5.80 or 6.45 was much smaller than that in solutions with $\mathrm{dU}$. Such a difference was not recorded when the starting $\mathrm{pH}$ was 7.28.

\section{Mean crystal volume}

The MCV was fairly constant for solutions both with and without $\mathrm{dU}$ at all three $\mathrm{pH}$ levels (Fig. 3). Only for solutions without $\mathrm{dU}$ and an initial $\mathrm{pH}$ of 5.80 and solutions 


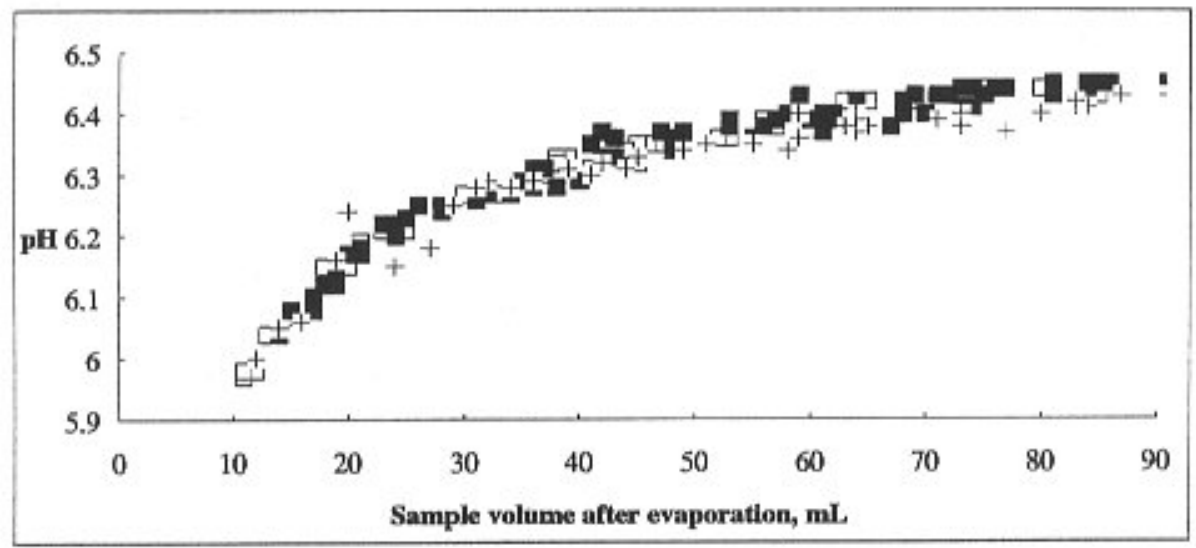

A

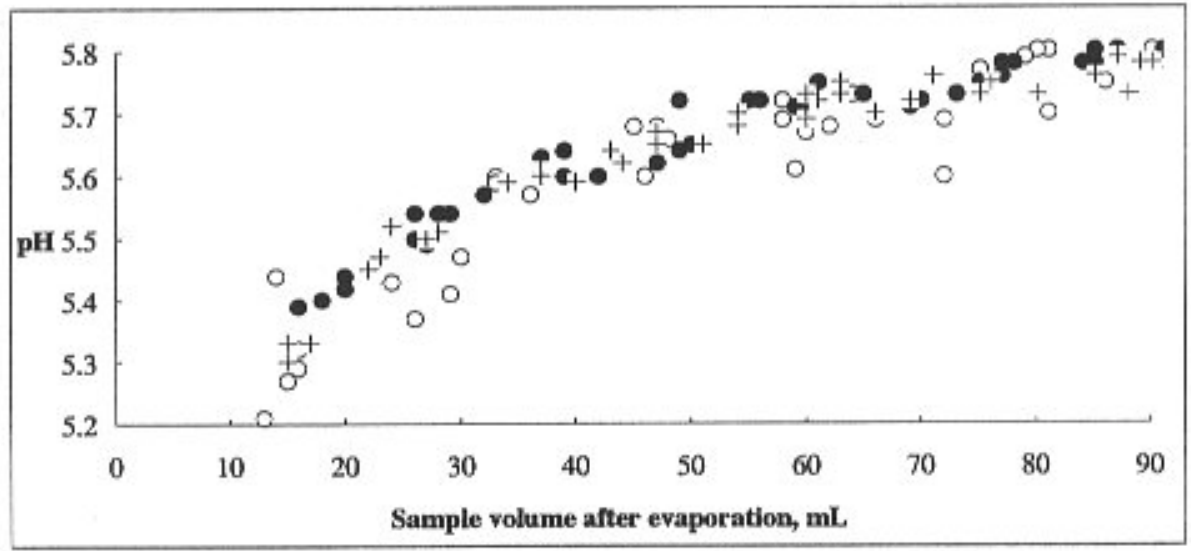

B

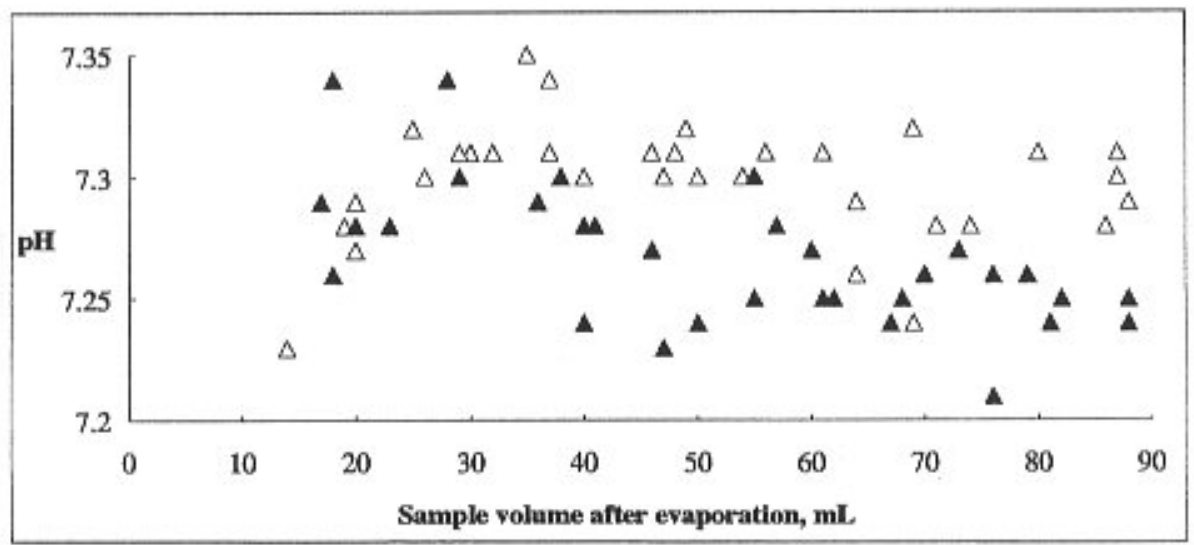

C

Figure 1. Effects on $\mathrm{pH}$ of volume reduction of $100 \mathrm{ml}$ solutions with an initial composition corresponding to that in the distal tubule. (A) Solutions with an initial pH of 6.45 without dialyzed urine (hollow squares), with $20 \%$ of dialyzed urine (solid squares) and without both dialyzed urine and calcium (+); (B) an initial $\mathrm{pH}$ of 5.80 without dialyzed urine (hollow circle), with $20 \%$ dialyzed urine (solid circles) and without both dialyzed urine and calcium (+); (C) an initial pH of 7.28 without dialyzed urine (hollow triangle) and with $20 \%$ dialyzed urine (solid triangle). 


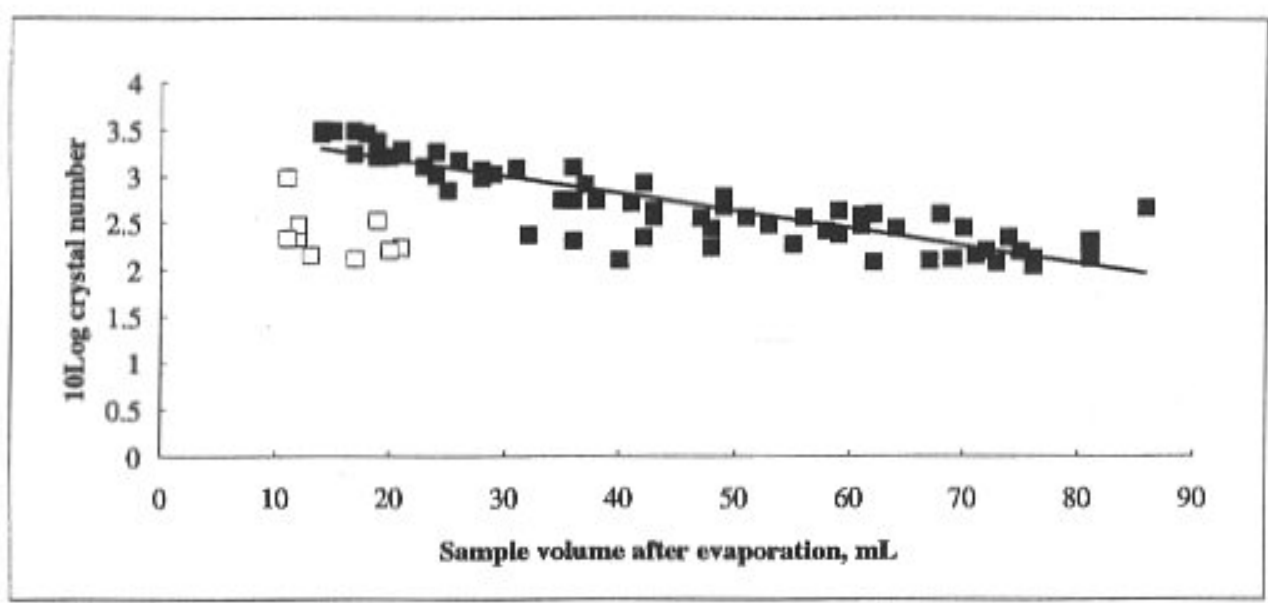

A

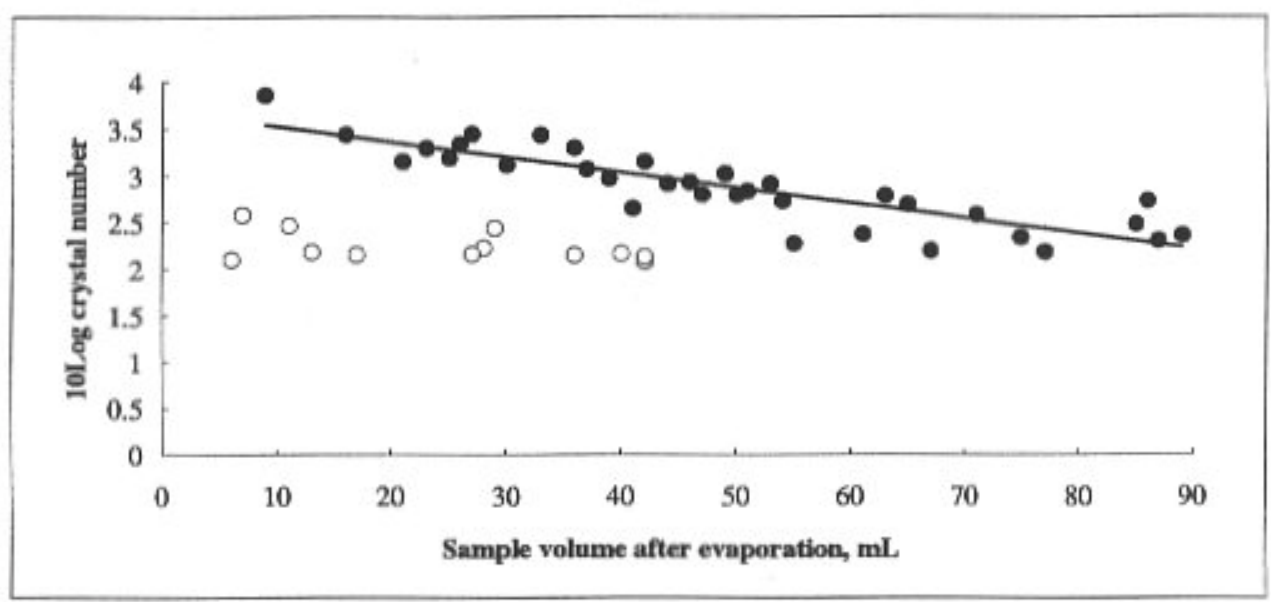

B

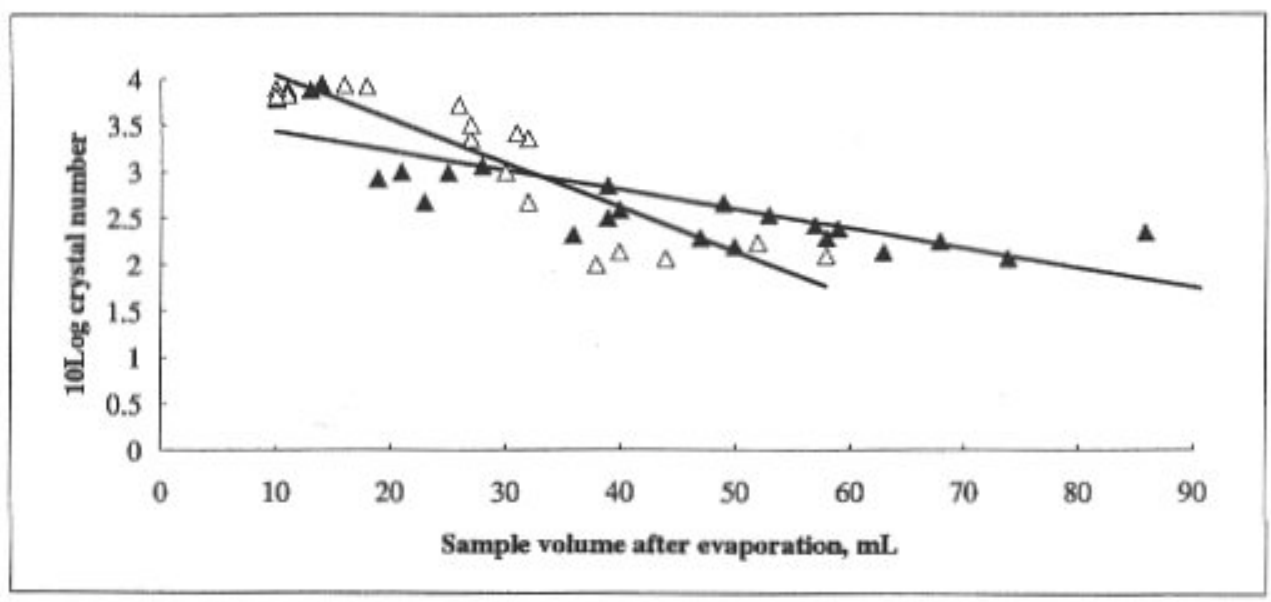

C

Figure 2. Relationship between the sample volume and the number of crystals after evaporation of $100 \mathrm{ml}$ samples with an initial composition corresponding to that in the distal tubule. (A) Solutions with an initial $\mathrm{pH}$ of 6.45 without dialyzed urine (hollow squares) and with $20 \%$ of dialyzed urine (solid squares); (B) an initial $\mathrm{pH}$ of 5.80 without dialyzed urine (hollow circle) and with $20 \%$ of dialyzed urine (solid circles); (C) an initial pH of 7.28 without dialyzed urine (hollow triangle) and with $20 \%$ dialyzed urine (solid triangle). 


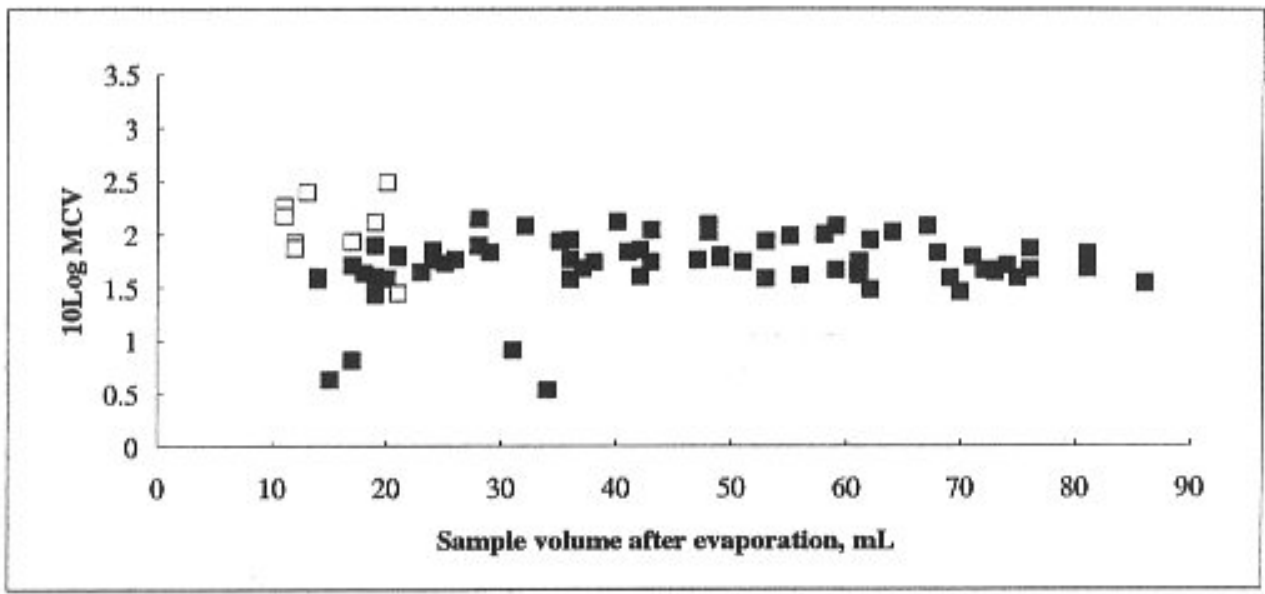

A

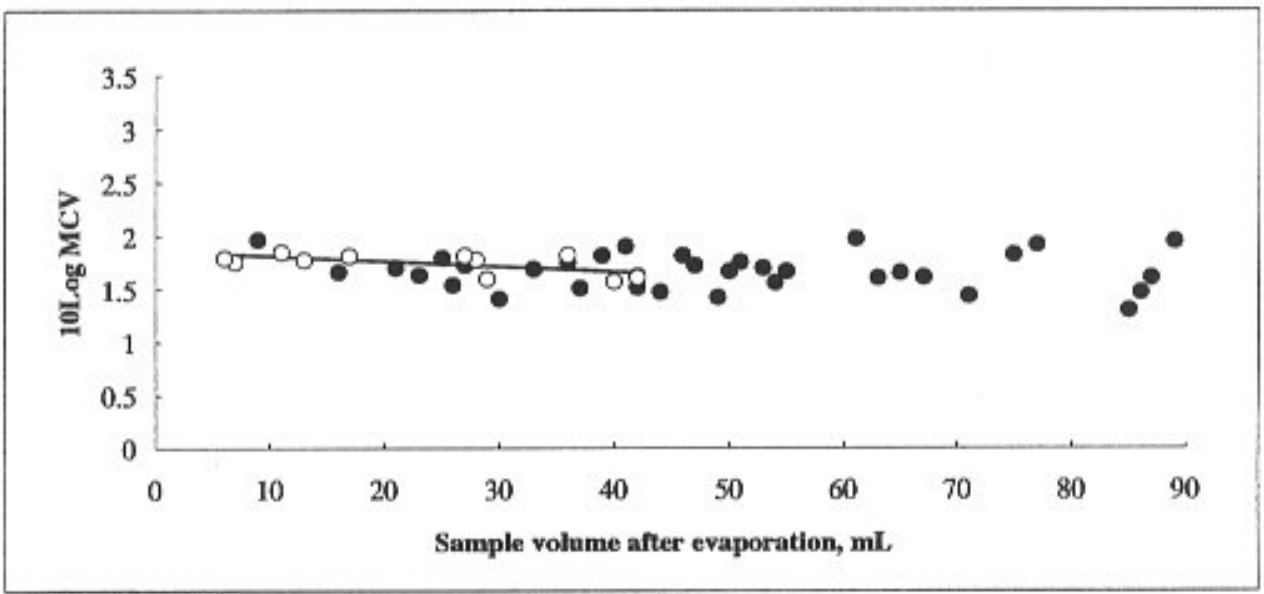

B

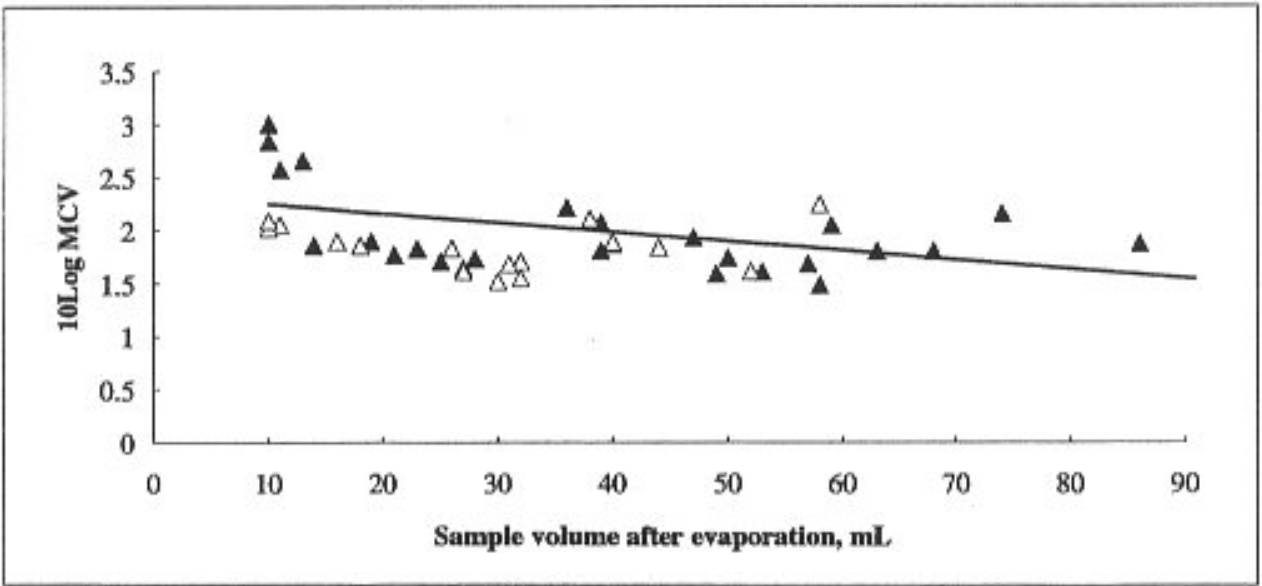

C

Figure 3. Relationship between the sample volume and the MCV after evaporation of $100 \mathrm{ml}$ samples with an initial composition corresponding to that in the distal tubuli. Evaporation was carried out of samples with (A) solutions with an initial $\mathrm{pH}$ of 6.45 without dialyzed urine (hollow squares) and with $20 \%$ of dialyzed urine (solid squares); (B) an initial pH of 5.80 without dialyzed urine (hollow circle) and with $20 \%$ of dialyzed urine (solid circles); (C) an initial pH of 7.28 without dialyzed urine (hollow triangle) and with $20 \%$ dialyzed urine (solid triangle). 
Table 1. Mean (standard deviation in parentheses) crystal volume (MCV) in solutions with and without dialyzed urine (dU) at different starting $\mathrm{pH}$.

\begin{tabular}{lll}
\hline \hline $\mathrm{pH}$ & Solution & MCV \\
\hline $\mathbf{p}>\mathbf{0 . 0 5}$ & & \\
5.80 & without dU & $1.74(0.10)$ \\
5.80 & with $20 \% \mathrm{dU}$ & $1.68(0.17)$ \\
$\mathbf{p}<\mathbf{0 . 0 5}$ & & \\
6.45 & without dU & $2.07(0.32)$ \\
6.45 & with $20 \% \mathrm{dU}$ & $1.71(0.30)$ \\
$\mathbf{p}>\mathbf{0 . 0 5}$ & & \\
7.28 & without dU & $1.84(0.22)$ \\
7.28 & with $20 \% \mathrm{dU}$ & $1.98(0.39)$ \\
\hline \hline
\end{tabular}

with $\mathrm{dU}$ and an initial $\mathrm{pH}$ of 7.28 was the relationship between the degree of volume reduction and the ${ }^{10} \log \mathrm{MCV}$ statistically significant; however, the slopes were weak.

From Figure 3A, it is evident that the MCV in the most concentrated samples was slightly greater without than with $\mathrm{dU}$ when the initial $\mathrm{pH}$ was 6.45 . In solutions with an initial $\mathrm{pH}$ of 7.28, the MCV remained at a constant level both in the presence and absence of $\mathrm{dU}$, except for the most concentrated samples (Fig. 3C). A fairly constant MCV was also recorded in dU containing samples with a starting $\mathrm{pH}$ of 6.45 and 5.80. The MCV recorded at each pH level is summarized in Table 1. The greatest MCV was found in solutions without $\mathrm{dU}$ and an initial $\mathrm{pH}$ of 6.45 , where the mean MCV was 2.07 compared with 1.74, in solutions without $\mathrm{dU}$ and an initial $\mathrm{pH}$ of 5.80, and 1.84, in solutions without $\mathrm{dU}$ and an initial $\mathrm{pH}$ of 7.28. The difference between the MCV in solutions without $\mathrm{dU}$ and initial $\mathrm{pH}$ of 5.80 and 6.45 was statistically significant ( $p<0.01$ ), whereas there was no significant difference between the MCV in solutions without $\mathrm{dU}$ and an initial $\mathrm{pH}$ of 5.80 and $7.28(\mathrm{p}>0.05)$ or an initial $\mathrm{pH}$ of 6.45 and 7.28 (p > 0.05). At a starting $\mathrm{pH}$ of 5.80 and 6.45 , the presence of $\mathrm{dU}$ resulted in a smaller MCV than when the starting $\mathrm{pH}$ was 7.28. When the dU containing solutions with different $\mathrm{pH}$ were compared, it was obvious that the MCV was greatest at a high $\mathrm{pH}$ and smallest at a low $\mathrm{pH}$. This difference was statistically significant $(\mathrm{p}<0.02)$.

\section{Crystal morphology}

Scanning electron microscopy showed a morphology in conformity with that of $\mathrm{CaP}$ crystals in solutions with an initial $\mathrm{pH}$ of 6.45 and 7.28 both in the presence and absence of dU (Figs. 4 and 6). The samples were all taken from solutions in which the volume had been reduced to 30 $40 \mathrm{ml}$, except for Figures 6E and 6F, which represent samples evaporated to a final volume around $20 \mathrm{ml}$. In the solutions with an initial $\mathrm{pH}$ of 5.80, however, the samples both with and without $\mathrm{dU}$ and reduced to a volume between 30 and 40 $\mathrm{ml}$ contained a precipitate suggestive of both $\mathrm{CaP}$ and $\mathrm{CaOx}$ (Fig. 5), the latter crystal phase was predominantly calcium oxalate dihydrate (COD) (Figs. 5E and 5F). The precipitate in solutions with an initial $\mathrm{pH}$ of 7.28 was strongly suggestive of hydroxyapatite, particularly when the volume had been reduced to around $20 \mathrm{ml}$ (Figs. 6E and 6F).

\section{Ion-activity products}

At a volume reduction to $40-30 \mathrm{ml}$, the $\mathrm{AP}_{\mathrm{CaOx}}$ was $0.41-0.56 \times 10^{-8} \mathrm{M}^{2}$, which only is about twice the solubility product of 0.23-0.25 x 10-8 $\mathrm{M}^{2}$ (Pak et al., 1975; Tomazic and Nancollas, 1979). Even following the pronounced volume reduction to $10 \mathrm{ml}$, the $\mathrm{AP}_{\mathrm{CaOx}}$ was not higher than $1.9 \times 10^{-8}$ $\mathrm{M}^{2}$. The $\mathrm{AP}_{\mathrm{CaP}}$ at volume reductions resulting in a significant crystallization ( $\geq 100$ crystals) for solutions with and without dU was $1.01 \times 10^{-14} \mathrm{M}^{2}$ and $1.78 \times 10^{-14} \mathrm{M}^{2}$, respectively, for samples with an initial $\mathrm{pH}$ of 5.80 (Table 2). The corresponding values for samples with an initial $\mathrm{pH}$ of 6.45 were $14.1 \times 10^{-14} \mathrm{M}^{2}$ and $44.3 \times 10^{-14} \mathrm{M}^{2}$; and for samples with an initial $\mathrm{pH}$ of 7.28 , they were $189 \times 10^{-14} \mathrm{M}^{2}$ and $288 \mathrm{x}$ $10^{-14} \mathrm{M}^{2}$ (Table 2). The $\mathrm{AP}_{\mathrm{Bru}}$ following evaporation of the solution with an initial $\mathrm{pH}$ of 5.80 to a volume of $40-30 \mathrm{ml}$ were $7.4 \times 10^{-8} \mathrm{M}^{2}$ and $9.6 \times 10^{-8} \mathrm{M}^{2}$, respectively. This should be compared with a solubility product of $1.9 \times 10^{-7}$ $\mathrm{M}^{2}$ (Koutsoukos and Nancollas, 1981). The $\mathrm{AP}_{\mathrm{HAP}}$ at volume reductions resulting in a significant crystallization were all much above the solubility product of $1.87 \times 10^{-59} \mathrm{M}^{9}$ (Koutsoukos and Nancollas, 1981), (Table 2), irrespective of the $\mathrm{pH}$ level.

\section{Discussion}

The objective of these experiments was to study the crystallization under conditions similar to those in the nephron. For this reason, solutions with compositions assumed to correspond to that in the distal part of the distal tubule (Lupták et al., 1994) were subjected to a volume reduction similar to that of urine during its passage from the distal tubule to the calyx. Urine will be concentrated on average six times as a result of water absorption in the collecting duct. It should be emphasized that the experimental model reflects effects brought about by changes in $\mathrm{pH}$ and supersaturation caused by this volume reduction. Other alterations, such as a reduced concentration of calcium or other ions as a result of reabsorption which normally takes place in the collecting duct, were not accounted for.

According to the definition given above, crystal appearance was recorded earlier in all samples containing $\mathrm{dU}$ than in those without $\mathrm{dU}$, irrespective of $\mathrm{pH}$. A more pronounced crystallization in terms of crystal number was 
$\mathrm{pH}$ and crystallization in the distal nephron

Table 2. The ion-activity products of calcium oxalate, calcium phosphate, hydroxyapatite and brushite in samples with and without dU, following evaporation to a volume resulting in a significant crystallization ( $\geq 100$ crystals).

\begin{tabular}{|c|c|c|c|c|c|c|}
\hline $\mathrm{pH}$ & Solution & $\begin{array}{l}\text { Volume } \\
(\mathrm{ml})\end{array}$ & $\begin{array}{l}\mathrm{AP}_{\mathrm{CaOx}} \\
10^{8} \mathrm{X} \mathrm{M}^{2}\end{array}$ & $\begin{array}{l}\mathrm{AP}_{\mathrm{CaP}} \\
10^{14} \mathrm{X} \mathrm{M}^{2}\end{array}$ & $\begin{array}{l}\mathrm{AP}_{\mathrm{HAP}} \\
10^{50} \mathrm{X} \mathrm{M}^{9}\end{array}$ & $\begin{array}{l}\mathrm{AP}_{\mathrm{Bru}} \\
10^{7} \mathrm{X} \mathrm{M}^{2}\end{array}$ \\
\hline 5.62 & without dU & 40 & 0.41 & 1.78 & 0.07 & 0.74 \\
\hline 5.78 & with dU & 90 & 0.17 & 1.01 & 0.002 & 0.29 \\
\hline 6.16 & without dU & 20 & 0.9 & 44.3 & 5460 & 5.3 \\
\hline 6.43 & with dU & 85 & 0.18 & 14.1 & 24.1 & 0.91 \\
\hline 7.28 & without dU & 60 & 0.26 & 288 & 3800000 & 2.61 \\
\hline 7.28 & with dU & 85 & 0.18 & 189 & 387000 & 1.72 \\
\hline
\end{tabular}

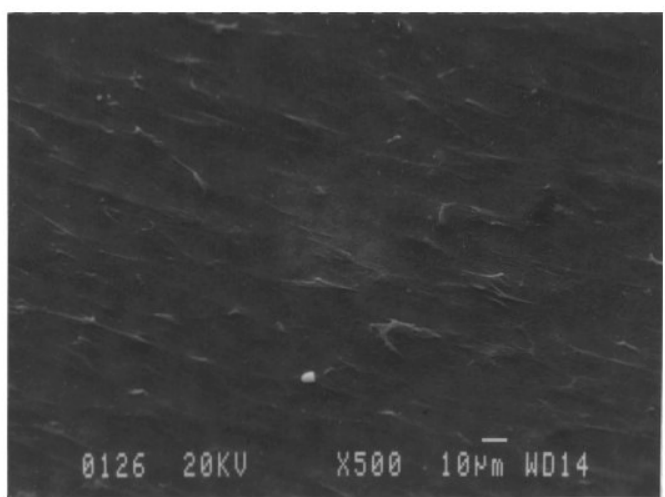

A

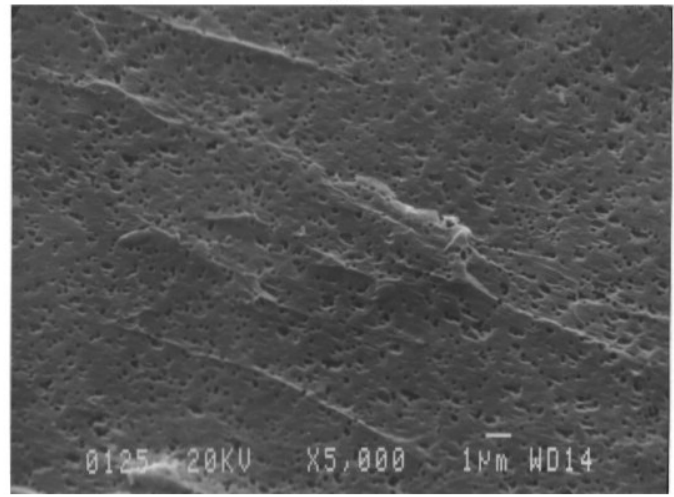

C

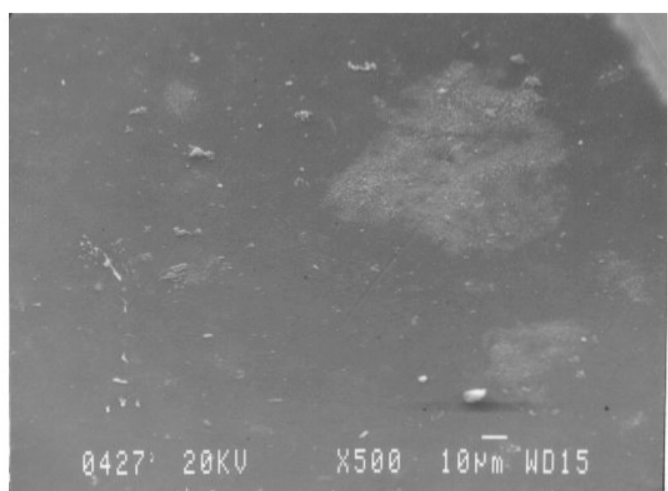

B

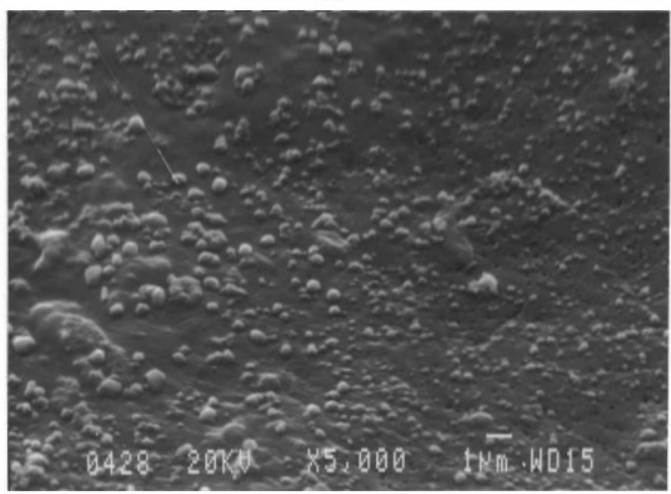

D

Figure 4. Scanning electron micrographs of the precipitate after evaporation of $100 \mathrm{ml}$ salt solutions with an initial $\mathrm{pH}$ of 6.45 to a final volume between $30-40 \mathrm{ml}$ : without $(\mathbf{A}$ and $\mathbf{C})$ and with $20 \%$ of dialyzed urine $(\mathbf{B}$ and $\mathbf{D})$ at low $(\mathbf{A}$ and $\mathbf{B}$, bars $=10 \mu \mathrm{m})$ and high magnifications ( $\mathbf{C}$ and $\mathbf{D}$, bars $=1 \mu \mathrm{m})$.

most clearly shown when the initial $\mathrm{pH}$ was 5.80 and 6.45 . At pH 7.28, no such difference was recorded. An outcome like this can be explained by nucleation of different crystal phases in the presence and absence of urinary macromolecules, but the similarity in crystal morphology between samples holding the same $\mathrm{pH}$ makes it reasonable to assume a modifying role of the macromolecules in $\mathrm{dU}$. An increased number of crystals in the measurable size interval can be explained by the formation of a larger number of crystal nuclei, a higher rate of crystal growth or 


\section{Højgaard et al.}

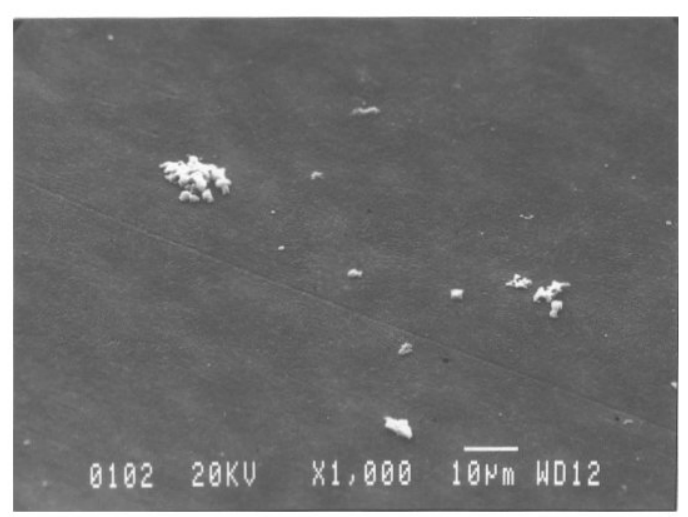

$\mathbf{A}$

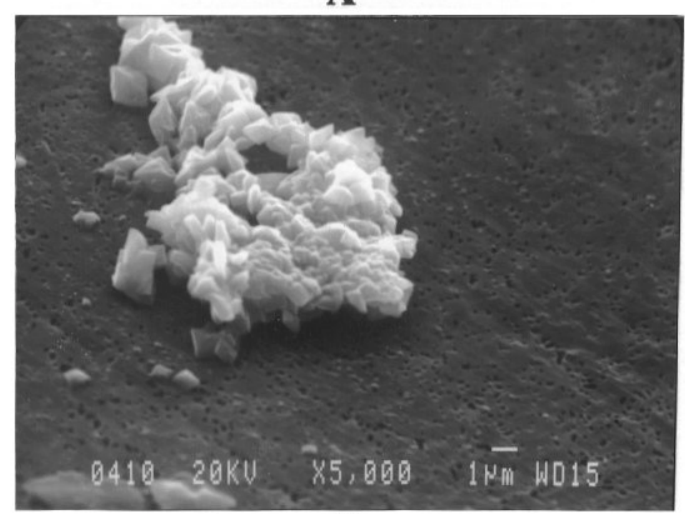

C

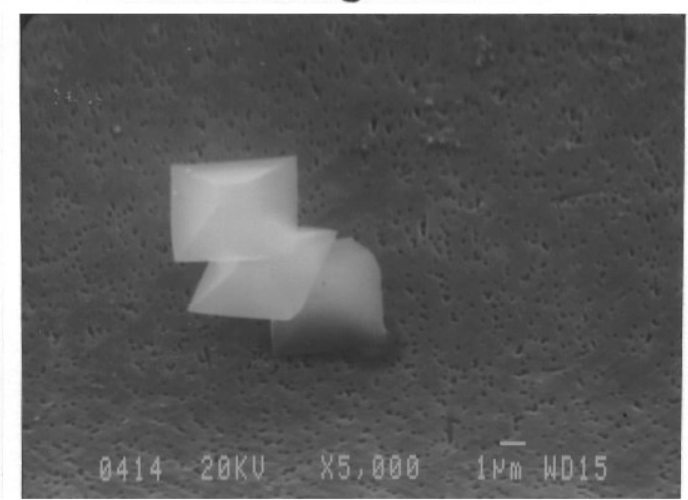

$\mathbf{E}$

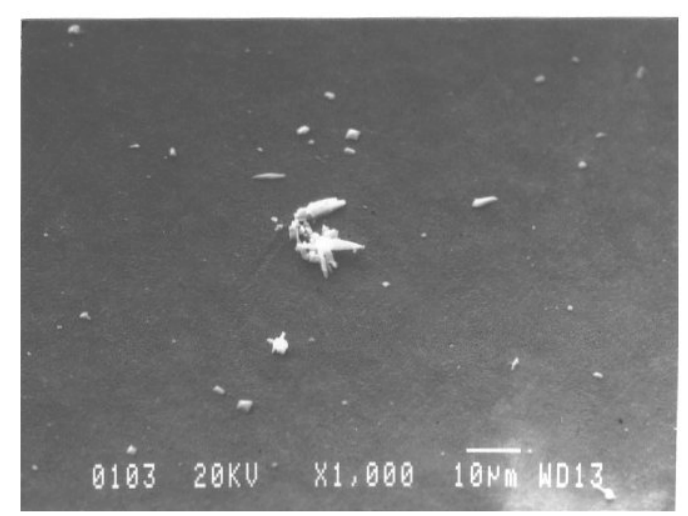

B

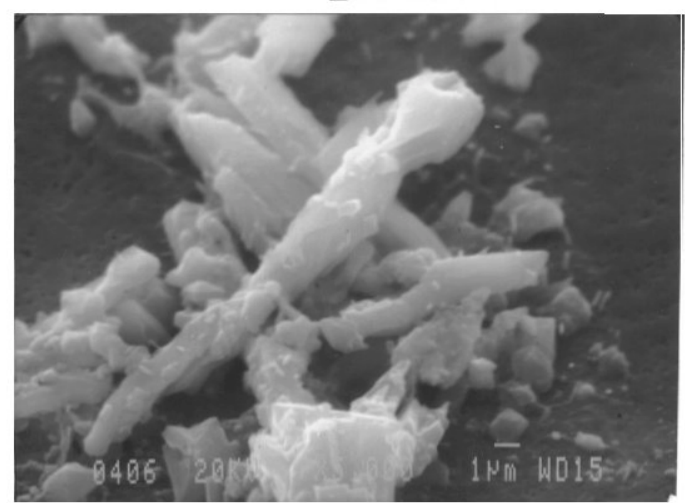

D

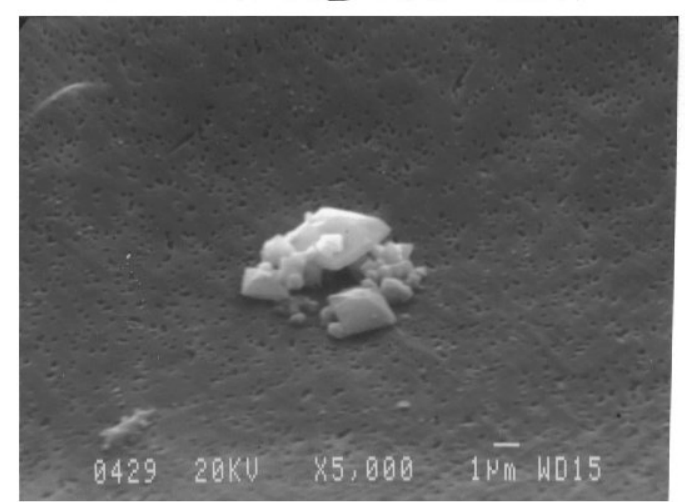

F

Figure 5. Scanning electron micrographs of the precipitate after evaporation of $100 \mathrm{ml}$ salt solutions with an initial $\mathrm{pH}$ of 5.80. Samples evaporated to a final volume between 30 to $40 \mathrm{ml}$ without dialyzed urine (A, C and E), and with $20 \%$ of dialyzed urine $(\mathbf{B}, \mathbf{D}$ and $\mathbf{F})$ at low $(\mathbf{A}$ and $\mathbf{B}$, bars $=10 \mu \mathrm{m})$ and high magnifications $(\mathbf{C}, \mathbf{D}, \mathbf{E}$, and $\mathbf{F}$, bars $=1 \mu \mathrm{m})$. Calcium oxalate dihydrate crystals are clearly seen at high magnification $(\mathbf{E}$ and $\mathbf{F})$.

agglomeration of initially small crystals or by the nucleation of a smaller number of crystals with a larger size. The present experiment does not allow definite conclusions in this respect, but the small effects on MCV during evaporation indicate that an effect on nucleation is most probable. Another possibility, that deserves some attention, is that $\mathrm{CaP}$ crystals that might have formed, dissolve when the $\mathrm{pH}$ is reduced and that such an effect is counteracted by protection of $\mathrm{CaP}$ crystals with urinary macromolecules.

Recent experimental results from our laboratory have shown that $\mathrm{CaP}$ crystals formed at a high $\mathrm{pH}$ might induce $\mathrm{CaOx}$ crystallization when exposed to urine with a lower $\mathrm{pH}$ (Tiselius et al., 1999; Højgaard et al., unpublished). In samples with an initial $\mathrm{pH}$ of 6.45 which is considered as an 


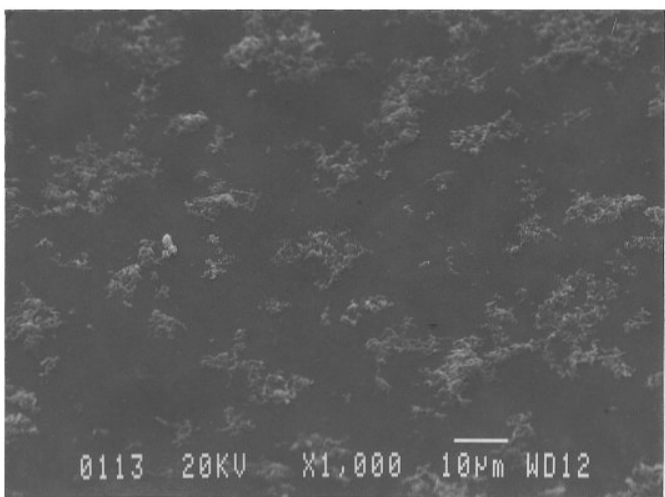

$\mathbf{A}$

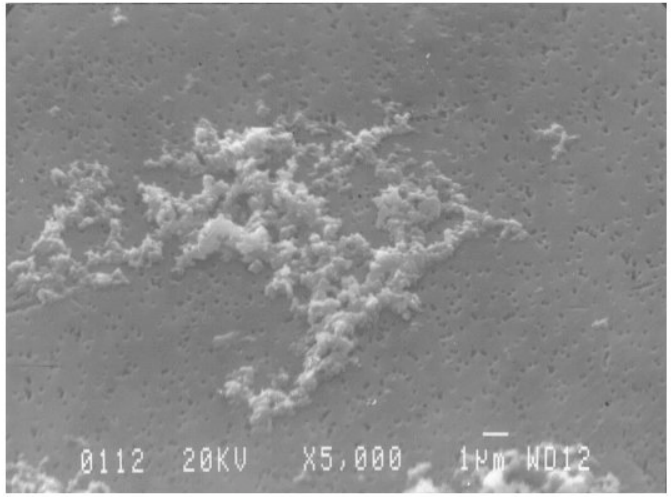

C

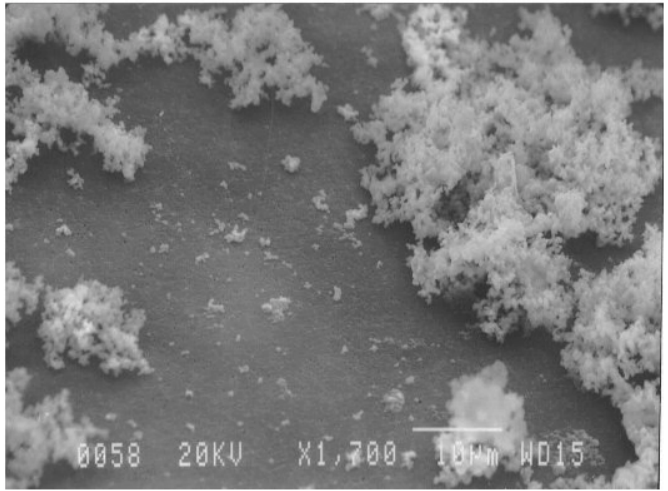

$\mathbf{E}$

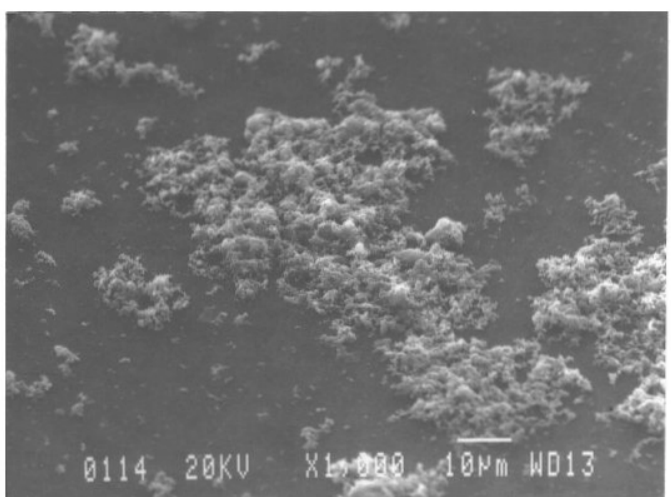

B

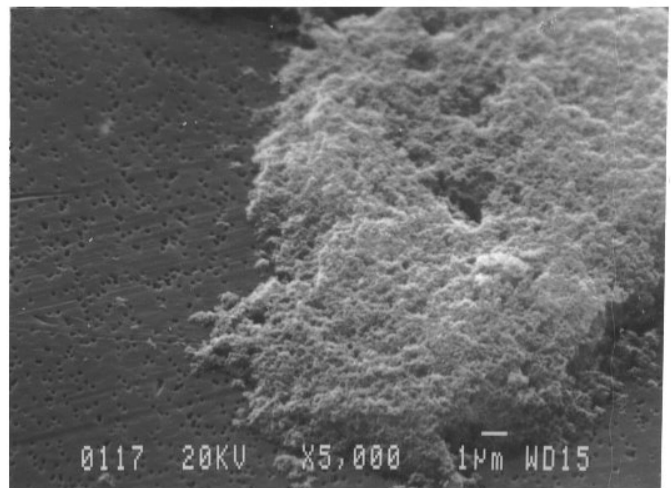

D

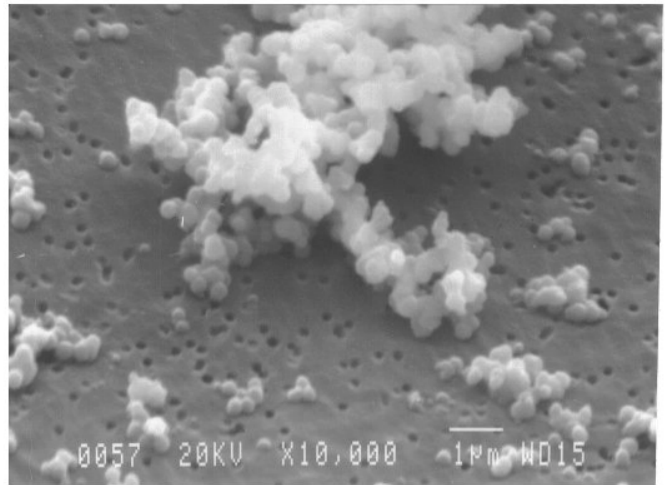

$\mathbf{F}$

Figure 6. Scanning electron micrographs of the precipitate after evaporation of $100 \mathrm{ml}$ salt solutions with an initial $\mathrm{pH}$ of 7.28 to a final volume between 30-40 ml: without dialyzed urine (A and C) and with $20 \%$ of dialyzed urine (B and D) at low (A and $\mathbf{B}$, bars $=10 \mu \mathrm{m})$ and high magnifications $(\mathbf{C}$ and $\mathbf{D}$, bars $=1 \mu \mathrm{m})$. Precipitate after evaporation to a final volume around $20 \mathrm{ml}$ of samples without dU are also shown at low $(\mathbf{E}$, bar $=10 \mu \mathrm{m})$ and high magnifications $(\mathbf{F}$, bar $=1 \mu \mathrm{m})$.

average normal $\mathrm{pH}$ in the distal tubule, volume reduction resulted in a nucleation of $\mathrm{CaP}$ (Højgaard et al., 1996). At a volume reduction to $30-40 \mathrm{ml}$, the $\mathrm{pH}$ was reduced to $6.2-$ 6.3. This did not result in the appearance of $\mathrm{CaOx}$, which is in agreement with observations that $\mathrm{CaP}$ crystal do not dissolve unless the $\mathrm{pH}$ is decreased to levels below 5.705.80 and that $\mathrm{CaOx}$ nucleation was not induced at $\mathrm{pH}$ levels above 6.10 (Tiselius et al., 1999).
In contrast, samples with a starting $\mathrm{pH}$ of $5.80 \mathrm{had}$ a $\mathrm{pH}$ around 5.6 at a volume reduction to $40 \mathrm{ml}$. In these samples, crystals of $\mathrm{CaOx}$ were formed. With an initial $\mathrm{pH}$ of 7.28, the number of crystals were similar with and without $\mathrm{dU}$, at least with a volume reduction of less than $90 \%$. Therefore, it can be assumed that at this high $\mathrm{pH}$, the driving force of $\mathrm{CaP}$ supersaturation is sufficient for a homogeneous 
nucleation, only marginally influenced by promoters.

Although dU obviously promoted the crystallization while maintaining the MCV at a fairly constant level, in the presence of dU, MCV was greatest at $\mathrm{pH} 7.28$ and 6.45.

It should be noted that the crystal counting of $\mathrm{CaP}$ is less accurate than that of $\mathrm{CaOx}$, particularly in the presence of great crystal masses. We believe, however, that the accuracy was sufficient for the conclusions drawn.

Crystals of $\mathrm{CaOx}$ were observed in samples with an ion-activity product of $0.41-0.56 \times 10^{-8} \mathrm{M}^{2}$. This level was derived from the urine composition in those samples where $\mathrm{CaOx}$ was first detected, but without attention to increments in the calcium concentration due to a possible $\mathrm{CaP}$ dissolution. Although previous studies have suggested a formation product of $\mathrm{CaOx}$ around $2 \times 10^{-8} \mathrm{M}^{2}$ (Robertson et al., 1968), a much lower saturation might be sufficient for inducing secondary $\mathrm{CaOx}$ nucleation, particularly in the presence of urinary macromolecules.

One important question is at which level of supersaturation CaP nucleation occurs. This is, of course, highly dependent on which crystal phase that forms, but without exact information in this respect we have found it of value to use the product of $\mathrm{a}_{\mathrm{Ca}} 2+\cdot \mathrm{a}_{\mathrm{PO} 4} 3$ - to express the ion-activity product of $\mathrm{CaP}$. From the data in Table 2, the lowest $\mathrm{AP}_{\mathrm{CaP}}$ at which crystals were observed was in samples with an initial $\mathrm{pH}$ of 5.80, whereas the corresponding values were much higher in samples with an initial $\mathrm{pH}$ of 7.28. It has previously been shown that brushite can precipitate in poorly supersaturated solutions with a low $\mathrm{pH}$, while other crystal phases of $\mathrm{CaP}$ form in solutions with higher a $\mathrm{pH}$ level and a higher CaP supersaturation (Abbona and Franchini-Angela, 1990; Lundager-Madsen and Christensson, 1991). A direct comparison between the crystallization in solutions with different $\mathrm{pH}$ is hampered by the fact that different crystal phases probably are precipitated, but it is reasonable to assume that other crystals phases than brushite would predominate in solutions with an initial $\mathrm{pH}$ of 6.45 and 7.28 , as suggested by the scanning electron microscopy in our experiments. Scanning electron microscopic analysis of samples containing $\mathrm{dU}$ with an initial $\mathrm{pH}$ of 5.80, reduced to a volume between 30 and $40 \mathrm{ml}$, showed a precipitate suggestive of both $\mathrm{CaOx}$ and $\mathrm{CaP}$. The ion-activity product of brushite in these solutions varied between $7.4 \times 10^{-8} \mathrm{M}^{2}$ and $9.6 \times 10^{-8} \mathrm{M}^{2}$, which is below the solubility product of $1.9 \times 10^{-7} \mathrm{M}^{2}$ (Koutsoukos and Nancollas, 1981). For this reason, it is unlikely that the $\mathrm{CaP}$ phase constitutes brushite.

The most important findings recorded in this series of experiments were that crystals occurred earlier in the presence of $\mathrm{dU}$, that the MCV was highest in samples with $\mathrm{pH} 7.28$ and that $\mathrm{CaOx}$ crystals only were observed following volume reduction of the samples with a starting $\mathrm{pH}$ of 5.80. For the subsequent development of $\mathrm{CaOx}$ crystal masses and stones, a dissolution of previously formed $\mathrm{CaP}$ crystals might be an important factor.

\section{Acknowledgements}

We are very grateful to Ms. Iréne Eriksson for the assistance with the EQUIL2 calculations and to Mr. BengtArne Fredriksson, for his help with the scanning electron microscopy. The study was supported by grants from the Maud and Birger Gustavsson Foundation.

\section{References}

Abbona F, Franchini-Angela M (1990) Crystallization of calcium and magnesium phosphates from solutions of low concentration. J Crystal Growth 104: 661-671.

Asplin JR, Mandel NS, Coe FL (1996) Evidence for calcium phosphate supersaturation in the loop of Henle. Am J Physiol 270: F604-F613.

Baumann JM, Ackermann D, Affolter B (1989) The influence of hydroxyapatite and pyrophosphate on the formation product of calcium oxalate at different $\mathrm{pHs}$. Urol Res 17: 153-155.

Berg C, Tiselius HG (1986) The effect of $\mathrm{pH}$ on the risk of calcium oxalate crystallization in urine. Eur Urol 12: 59-61.

Boevé ER, Cao LC, De Bruijn WC, Robertson WG, Romijn JC, Schröder H (1994) Zeta potential distribution on calcium oxalate crystal and Tamm-Horsfall protein surface analyzed with doppler electrophoretic light scattering. J Urol 152: 531-536.

Coe Fl, Parks JH (1990) Defenses of an unstable compromise: Crystallization inhibitors and the kidney's role in mineral regulation. Kidney Int 38: 625-631.

Coe FL, Nakagawa Y, Parks JH (1991) Inhibitors within the nephron. Am J Kidney Diseases XVII: 407-413.

Grases F, Costa-Bauzá A, March JG, Söhnel O (1993) Artificial simulation of renal stone formation. Nephron $\mathbf{6 5}$ : 77-81.

Hallson PC, Rose GA (1989a) Risk factors for urinary calcium oxalate crystals as revealed by their specific enzymatic assay. Br J Urol 64: 451-457.

Hallson PC, Rose GA (1989b) Measurement of calcium phosphate crystalluria: Influence of $\mathrm{pH}$ and osmolality and invariable presence of oxalate. Br J Urol 64: 458-462.

Hess B, Nakagawa Y, Coe FL (1989) Inhibition of calcium oxalate monohydrate crystal aggregation by urine proteins. Am J Physiol 257: F99-F106.

Højgaard I, Fornander AM, Nilsson MA, Tiselius HG (1996) Crystallization during volume reduction of solutions with an ion-composition corresponding to that in the distal tubuli. Scanning Microsc 10: 487-498.

Kok DJ (1995) Intratubular crystallization events. In: 
$\mathrm{pH}$ and crystallization in the distal nephron

Renal Stones: Aspects on Their Formation, Removal and Prevention. Proceedings of the Sixth European Symposium on Urolithiasis. Tiselius HG (ed.). Akademitryck AB, Edsbruk, Sweden. pp 26-29.

Koutsoukos PG, Nancollas GH (1981) Crystal growth of calcium phosphates - epitaxial considerations. J Crystal Growth 53: 10-19.

Lundager-Madsen HE, Christensson F (1991) Precipitation of calcium phosphate at $40^{\circ} \mathrm{C}$ from neutral solution. J Crystal Growth 114: 613-618.

Lupták J, Jensen HB, Fornander AM, Højgaard I, Nilsson MA, Tiselius HG (1994) Crystallization of calcium oxalate and calcium phosphate at supersaturation levels corresponding to those in different parts of the nephron. Scanning Microsc 8: 47-61.

Pak CYC, Ohata M and Holt K (1975) Effect of diphosphonate on crystallization of calcium oxalate in vitro. Kidney Int 7: 154-160.

Rector FC Jr (1983) Acidification of the urine In: Renal Physiology, Section 8, Handbook of Physiology. Geiger SR, Orloff J, Berliner RW (eds.). American Physiol. Soc., Washington, DC. pp. 431-454.

Robertson WG, Peacock M, Nordin BEC (1968) Activity products in stone-forming and non-stone forming urine. Clin Sci 34: 579-594.

Robertson WG, Peacock M, Heyburn PJ, Marshall DH, Clark PB (1978) Risk factors in calcium stone disease of the urinary tract. Br J Urol 50: 449-454.

Scurr DS, Robertson WG (1986) Modifiers of calcium oxalate crystallization found in urine: III studies on the role of Tamm-Horsfall mucoprotein and of ionic strength. J Urol 136: 505-507.

Smith LH (1976) Application of physical, chemical, and metabolic factors to the management of urolithiasis. In: Urolithiasis Research. Fleisch H, Robertson WG, Smith LH, Vahlensieck W (eds.). Plenum Press, New York. p. 199-211.

Tiselius HG (1981) The effect of $\mathrm{pH}$ on the urinary inhibition of calcium oxalate crystal growth. Br J Urol 53: 470-474.

Tiselius HG (1983) Different estimates of the risk of calcium oxalate crystallization in urine. Eur Urol 9: 231-234.

Tiselius HG, Fornander AM, Nilsson MA (1999) Studies on the crystallization process following addition of calcium phosphate crystals to solutions with a composition corresponding to that in the collecting duct. Scanning Microsc 13: (this issue)

Tomazic B, Nancollas GH (1979) The kinetics of dissolution of calcium oxalate hydrates. J Crystal Growth 46: $355-361$.

Werness PG, Brown CM, Smith LH and Finlayson B (1985) EQUIL2: Basic computer program for the calculation of urinary saturation. J Urol 134: 1242-1244.

Wilson JWL, Werness PG, Smith LH (1985) Inhibi- tors of crystal growth of hydroxyapatite: A constant composition approach. J Urol 134: 1255-1258.

\section{Discussion with Reviewers}

L.C. Cao: Is it possible to really control CaP crystal formation in the upper nephron to prevent $\mathrm{CaOx}$ stone formation?

Authors: It probably is very difficult to change urine composition and $\mathrm{CaP}$ supersaturation in the upper parts of the nephron. We believe, however, that steps can be taken to avoid periods of excessive alkalinization in the distal part of the distal tubule as well as in the upper part of the collecting duct. Although a high fluid intake results in reduced calcium and phosphate concentrations, this effect undoubtedly will be most pronounced in the collecting duct. To our knowledge, there are no experimental studies from which conclusions in this respect can be drawn and it remains to be shown whether a reduced $\mathrm{pH}$ or a reduced concentration of calcium and phosphate in the distal part of the distal tubule or in the proximal part of the collecting duct can reduce the risk of $\mathrm{CaOx}$ crystal formation.

F. Grases: Do you think that the crystals formed in the distal tubules can obstruct them? If this would be the case, what type of renal calculi would be formed? If crystals formed in the distal tubules are not retained there or within the collecting ducts, can they induce renal calculus formation? Why and where?

Authors: Our reply to this question can only be speculative, but it seems unlikely that $\mathrm{CaP}$ crystals formed in the distal tubule will obstruct the lumen at this level. Such a mechanism would result in intrarenal $\mathrm{CaP}$ concrement formation and this is not a common clinical finding. We rather believe that large $\mathrm{CaP}$ aggregates adhere to the tubular wall and, thus, move slowly down the nephron. By such a mechanism, the $\mathrm{CaP}$ crystal material can be retained so that it occasionally will be exposed to a urine with a low $\mathrm{pH}$. Dissolution of CaP crystals can, in that way, bring about a high local concentration of calcium in the macromolecular layer surrounding the crystals and provide the necessary prerequisites for $\mathrm{CaOx}$ nucleation. 